\title{
FAKTOR-FAKTOR YANG MEMPENGARUHI PERBEDAAN BERAT BADAN LAHIR BAYI DI RSUD. Dr. M . YUNUS KOTA BENGKULU
}

\author{
Meli Marisiantini, Ratna Dewi \\ Politeknik Kesehatan Kementerian Kesehatan Bengkulu, Jurusan Kebidanan \\ Jalan Indragiri Nomor 03 Padang Harapan Bengkulu \\ marisiantini26@gmail.com
}

\begin{abstract}
Nowadays, Infant Mortality Rate (IMR) is still high in Indonesia, it is about 32 per 1.000 live births, and low birth weight infants accounted for $34 \%$ as the major cause (SDKI, 2012). In Dr.M.Yunus hospital at Bengkulu city, cases of $L B W$ has increased from the preceding year, approximately 391 infants (14.4\%) of 2713 childbirths. The purpose of this research is known the factors which affect average of birth weight infants in C1 Midwifery room at Dr.M.Yunus Bengkulu in 2013. The study design was observational descriptive with cross-sectional method which the population are women who delivered in the maternity room at Dr.M.Yunus hospital, and also with accidental sampling technique which samples are 48 respondents, data were processed using univariate and bivariate. The results of statistical tests showed there are influences of those factors to affect average of birth weight infant in Dr.M.Yunus hospital in 2013 and long-standing is the most dominant factor. It is expected that health workers can be provide counseling to pregnant women in order to know the risks if the women have a bad lifestyle (exposure to cigarette smoke, caffeine consumption, and prolonged standing) and also set the age for pregnancy planning.
\end{abstract}

Keywords: age, cigarette smoke exposure, caffeine, standing for longtime, birth weight infants

\begin{abstract}
Abstrak : Di Indonesia saat ini angka kematian neonatal masih tinggi yaitu 32/1.000 kelahiran hidup, dan BBLR menyumbang 34\% sebagai penyebabnya (SDKI,2012). Kasus BBLR di RSUD Dr.M.Yunus Kota Bengkulu mengalami peningkatan dari tahun sebelumnya yaitu berjumlah 391 bayi $(14,4 \%)$ dari 2713 persalinan. Tujuan penelitian ini adalah diketahuinya faktor-faktor yang mempengaruhi perbedaan berat badan lahir bayi di ruang C1 Kebidanan RSUD Dr. M. Yunus Bengkulu tahun 2013. Desain penelitian adalah observasional deskriptif dengan metode potong silang dengan populasi seluruh ibu bersalin di ruang C1 kebidanan RSUD Dr. M. Yunus, teknik pengambilan sampel accidental sampling dengan jumlah sampel 48 responden, pengambilan yang diolah secara univariat dan bivariat. Hasil penelitian menunjukkan ada pengaruh faktor-faktor tersebut terhadap berat badan lahir bayi di RSUD Dr. M. Yunus Bengkulu tahun 2013 dan faktor yang paling dominan adalah lama berdiri. Diharapkan pada petugas kesehatan agar memberikan konseling kepada ibu hamil agar memahami risiko yang dapat timbul pada ibu yang memiliki gaya hidup buruk (terpapar asap rokok, konsumsi kafein, serta terlalu lama berdiri) serta agar mengatur usia untuk perencanaan kehamilan.
\end{abstract}

Kata kunci : usia, asap rokok, kafein, lama berdiri, berat badan lahir bayi

Berat badan lahir bayi merupakan indikator yang penting dan reliabel bagi kelangsungan hidup neonatus dan bayi, baik ditinjau dari segi pertumbuhan fisik dan perkembangan status mentalnya. Berat badan lahir bayi juga dapat digunakan sebagai indikator umum untuk mengetahui status kesehatan, gizi dan sosial ekonomi dari negara maju dan negara berkembang. (Phaneendra 2001 dalam Budiman, 2011).

Bayi berat lahir rendah (BBLR) menyumbang 42,5-56\% kematian perinatal. Risiko kematian BBLR lebih dari 2 kali angka kematian bayi cukup bulan serta BBLR menyumbang 5-9 kali risiko kematian diban- dingkan dengan bayi dengan berat badan lahir normal (Winkjosastro, 2006). Secara statistik menunjukkan $90 \%$ kejadian berat badan lahir rendah terdapat di negara berkembang dan angka kematiannya 35x lebih tinggi dibanding pada bayi dengan berat lahir normal (WHO, 2007). Di antara 18 negara di Asia, rata-rata $13,0 \%$ dari seluruh persalinan (kira-kira 1 dari 7 kelahiran) adalah BBLR. (OECD, 2012).

Di Indonesia, sebagian besar kematian neonatal terjadi pada $0-6$ hari $(78,5 \%)$, dari angka kematian ini sebanyak $47 \%$ meninggal pada masa neonatal. Target pencapaian Millennium Development Goal's (MDG's) yang harus dicapai pada tahun 2015 yaitu 
Angka Kematian Bayi (AKB) sebesar 23/1.000 kelahiran hidup sedangkan menurut hasil Survei Demografi dan Kesehatan Indonesia (SDKI) tahun 2012, AKB di Indonesia masih 32/1.000 kelahiran hidup (SDKI, 2012). Sedangkan menurut dari data profil provinsi Bengkulu, jumlah angka kematian neonatal di provinsi Bengkulu mengalami peningkatan dimana pada tahun 2010 mencapai 8,4 per 1.000 kelahiran hidup per tahun menjadi 11,8 per 1.000 kelahiran hidup per tahun (Dinkes Provinsi Bengkulu, 2012).

Adapun penyebab kematian bayi baru lahir di Indonesia yaitu prematuritas dan Berat Badan Lahir Rendah (BBLR) (34\%), asfiksia (27\%), sepsis (12\%), hipotermi (7\%), ikterus $(6 \%)$, post matur $(5 \%)$ dan kelainan kongenital (1\%) (Depkes. RI, 2008), sehingga dapat disimpulkan di sini bahwa penyebab utama kematian neonatal adalah bayi berat lahir rendah (BBLR).

Menurut Shelov (2005), banyak faktor risiko yang diketahui berhubungan dengan berat badan lahir rendah, seperti riwayat obstetrik, etnis, genetik, serta tidak berada dalam kontrol langsung wanita. Berat badan lahir bayi juga dipengaruhi oleh beberapa faktor, yakni komplikasi kehamilan, penyakit dalam kehamilan, lamanya usia kehamilan, nutrisi selama hamil serta kebiasaan ibu merokok, minum minuman keras atau penggunaan narkoba. Sedangkan, menurut Proverawati (2010), beberapa faktor lainnya yang ikut mempengaruhi berat badan lahir bayi adalah faktor ibu (usia, paritas, jarak kehamilan, status gizi, pendidikan dan sosial ekonomi), faktor janin (kelainan kromosom, infeksi janin kronik, serta kehamilan gameli), faktor plasenta, perilaku gaya hidup (paparan asap rokok, terlalu lama berdiri, dan konsumsi kafein) memainkan peran penting dalam menentukan pertumbuhan janin serta faktor lingkungan (radiasi, tinggal di dataran tinggi, paparan zat-zat racun) (Proverawati, 2010).

Usia wanita dapat mempengaruhi kehamilannya. Kehamilan pada usia muda merupakan faktor resiko. Hal ini disebabkan belum matangnya organ reproduksi untuk hamil (endometrium belum sempurna) sedangkan pada usia diatas 35 tahun endometrium yang kurang subur serta memperbesar kemungkinan untuk menderita kelainan kongenital, sehingga dapat berakibat terhadap kesehatan ibu maupun perkembangan dan pertumbuhan janin dan beresiko untuk mengalami kelahiran prematur. Hal ini sesuai dengan penelitian Sistiarni (2008), menunjukkan bahwa ada hubungan antara variabel yang usia ibu dengan kejadian BBLR.

Ibu hamil juga dipengaruhi oleh paparan asap. Asap yang terhisap oleh ibu mempengaruhi peredaran darah dan membuat ibu terpajan bahan kimia berbahaya yang bisa mengganggu perkembangan bayi (Bobak \& Jensen, 2004). Hal ini didukung oleh penelitian yang dilakukan oleh Sirajuddin, dkk (2011) bahwa ada korelasi positif asap rokok terhadap berat badan bayi lahir.

Ibu hamil yang pekerjaannya mengharuskan ia berdiri terlalu lama atau lebih dari 40 jam dalam seminggu, juga beresiko tinggi memiliki bayi yang lebih kecil. Dalam penelitian yang dimuat dalam jurnal Occupational and Environmental Medicine, para peneliti mengungkapkan kaitan antara lingkungan pekerjaan dan ukuran bayi. Beberapa jenis profesi yang mengharuskan seseorang berdiri lama antara lain guru, koki, kasir, peneliti, perawat, dan masih banyak lagi. Dalam analisis longitudinal, perempuan yang kadang-kadang atau sering berdiri dalam waktu yang lama pada pekerjaannya kemungkinan melahirkan bayi dengan lingkar kepala yang lebih kecil bila dibandingkan dengan bayi dari ibu yang tidak bekerja dalam waktu yang lama.

Bech dkk dalam Mardiawati (2011), mengatakan konsumsi kafein yang tinggi juga dapat menyebabkan vasokonstriksi utero plasental, yang kemudian akan mengakibatkan malformasi fetus, infertilitas pada ibu, dan keadaan berat badan lahir rendah. Hal ini juga sejalan dengan penelitian yang dilakukan oleh Dewi Mardiawati (2011), yang menunjukkan terdapat hubungan yang bermakna antara konsumsi kafein dengan berat badan lahir.

Berdasarkan survey awal yang dilakukan peneliti, diperoleh data BBLR dari Rekam Medik RSUD Dr. M. Yunus Bengkulu dengan perincian pada tahun 2009 terdapat 126 
(6,4\%) kasus BBLR dari 1978 persalinan, sementara itu pada tahun 2010 terdapat 191 $(11,5 \%)$ kasus BBLR dari 1660 persalinan, sedangkan tahun 2011 terdapat $205(8,4 \%)$ kasus BBLR dari 2446 persalinan, sedangkan tahun 2012 meningkat menjadi $391(14,4 \%)$ kasus BBLR dari 2713 persalinan.

Sedangkan, survey awal yang dilakukan peneliti di ruang C1 Kebidanan RSUD Dr. M. Yunus Kota Bengkulu pada 30 Oktober sampai dengan 2 November 2013, terdapat 10 bayi dengan BBLR, tiga ibu berusia $<20$ tahun dengan, tiga ibu berusia $>35$ tahun satu di antaranya mempunyai kebiasaan minum kopi. Satu ibu bekerja sebagai salesman susu, sedangkan semua suami merupakan perokok aktif

Berdasarkan hal tersebut, maka tujuan penelitian ini adalah untuk mengetahui faktorfaktor yang mempengaruhi perbedaan berat badan lahir bayi di ruang $\mathrm{C} 1$ Kebidanan RSUD Dr M. Yunus Bengkulu tahun 2013.

\section{BAHAN DAN CARA KERJA}

Penelitian ini merupakan jenis penelitian observasional deskriptif dengan menggunakan rancangan potong silang. Populasi dalam penelitian ini adalah semua ibu bersalin di ruang bangsal $\mathrm{C} 1$ kebidanan RSUD Dr. M. Yunus. Sampel diambil dari populasi yang ada secara accidental sampling dengan kriteria inklusi sebagai berikut: semua ibu dan bayinya yang dilahirkan di RSUD dr. M. Yunus tahun 2013. Sedangkan kriteria eksklusinya adalah ibu dengan bayi gameli dan atau dengan kelainan kongenital. Pengumpulan data menggunakan data primer dengan membagikan kuesioner kepada responden sesuai kriteria inklusi dan eksklusi tersebut.

Pengumpulan data dilakukan dengan membagikan kuesioner kepada seluruh ibu bersalin di ruang bangsal $\mathrm{C} 1$ kebidanan RSUD Dr. M. Yunus selama 2 minggu terhitung dari 15 Januari - 31 Januari 2014. Data yang terkumpul akan dilakukan pemeriksaan data (data cleaning), koding, tabulasi dan selanjutnya akan diolah dengan menggunakan program SPSS. Analisis yang dilakukan adalah analisis univariabel untuk mendeskripsikan hasil penelitian dan analisis bivariabel menggunakan uji T-independent dengan tingkat kemaknaan $p<0,05$. Sebelum dilakukan uji-T terlebih dahulu dilakukan uji normalitas data pada semua variabel. Berdasarkan hasil Uji Kolmogorov-Smirnov diperoleh nilai signifikan $(p)=0,191>0,05$, jadi data berdistribusi normal sehingga memenuhi syarat untuk dilakukan uji $\mathrm{T}$.

\section{HASIL}

\section{Analisis Univariat}

Tabel 1. Distribusi Frekuensi Usia, Paparan Asap Rokok, Lama Berdiri, Konsumsi Kafein dengan Berat Badan Lahir Bayi

\begin{tabular}{|c|c|c|}
\hline \multirow{2}{*}{ Variabel } & \multicolumn{2}{|c|}{ Distribusi Frekuensi } \\
\hline & $(n=48)$ & $\%$ \\
\hline \multicolumn{3}{|l|}{$\begin{array}{l}\text { Usia Ibu } \\
<20 \text { Tahun atau > } 35\end{array}$} \\
\hline Tahun & 18 & 37,5 \\
\hline 20-35 Tahun & 30 & 62,5 \\
\hline \multicolumn{3}{|l|}{ Paparan Asap Rokok } \\
\hline Ya & 32 & 66,7 \\
\hline Tidak & 16 & 33,3 \\
\hline \multicolumn{3}{|l|}{ Terlalu Lama Berdiri } \\
\hline$\geq 40 \mathrm{jam} / \mathrm{minggu}$ & 15 & 31,2 \\
\hline$<40 \mathrm{jam} / \mathrm{minggu}$ & 33 & 68,8 \\
\hline \multicolumn{3}{|l|}{ Konsumsi Kafein } \\
\hline$<4$ gelas sehari & 31 & 64,6 \\
\hline $\begin{array}{l}\text { Tidak mengkonsumsi } \\
\text { kafein }\end{array}$ & $\begin{array}{l}51 \\
17\end{array}$ & 35,4 \\
\hline
\end{tabular}

\section{Data Primer}

Tabel 1 menunjukkan bahwa hampir sebagian responden $(37,5 \%)$ berusia $<20$ atau $>35$ tahun, selanjutnya sebagian besar responden $(66,7 \%)$ terpapar asap rokok, sedangkan hampir sebagian responden $(31,2 \%)$ berdiri $\geq 40$ jam dalam seminggu selama melakukan aktivitas selama masa kehamilan, dan juga sebagian besar responden $(64,6 \%)$ mengkonsumsi kafein $<4$ gelas sehari.

Tabel 2 Rata-rata Berat Badan Lahir Bayi

\begin{tabular}{lccccc}
\hline Variabel & n & Mean & Median & SD & $\begin{array}{c}\text { Min-Max } \\
(\text { gr })\end{array}$ \\
\hline $\begin{array}{l}\text { Berat } \\
\text { Badan }\end{array}$ & 48 & 2827,08 & 2800,00 & 628,994 & $1500-4300$ \\
Lahir Bayi & & & & & \\
\hline
\end{tabular}

Dari Tabel 2 di atas dapat dilihat bahwa rata-rata berat badan lahir bayi di RSUD Dr. M. Yunus Kota Bengkulu adalah 2827 gram dengan berat badan lahir bayi yang terendah 1500 gram dan berat badan lahir bayi tertinggi 4300 gram. 


\section{Analisis Bivariat}

Tabel 3 Perbedaan Rata-rata Berat Badan Lahir Bayi Berdasarkan Faktor yang Mempengaruhi selama Hamil dari Ibu Bersalin di RSUD Dr. M. Yunus Bengkulu Tahun 2013

\begin{tabular}{|c|c|c|c|c|c|c|}
\hline Variabel & $\mathbf{n}$ & $\begin{array}{l}\text { Rata-rata Berat } \\
\text { Badan Lahir Bayi }\end{array}$ & Beda Mean & SD & $\mathbf{p}$ & $95 \% \mathrm{CI}$ \\
\hline \multicolumn{7}{|l|}{ Usia } \\
\hline $\begin{array}{l}<20 \text { Tahun } \\
\text { atau }>35 \text { Tahun }\end{array}$ & 18 & $2.544,44$ & 452,222 & 614,743 & 0,014 & $2238,74-2850,15$ \\
\hline 20-35 Tahun & 30 & $2.996,67$ & & 583,381 & & $2778,83-3214,50$ \\
\hline \multicolumn{7}{|l|}{ Paparan Asap Rokok } \\
\hline Ya & 32 & $2.687,50$ & 418,750 & 598,789 & 0,028 & $2471,61-2903,39$ \\
\hline Tidak & 16 & $3.106,25$ & & 611,521 & & $2780,39-3432,11$ \\
\hline \multicolumn{7}{|l|}{ Lama Berdiri } \\
\hline$\geq 40 \mathrm{jam} / \mathrm{minggu}$ & 15 & $2.366,67$ & 669.697 & 408,248 & 0,000 & $2140,59-2592,75$ \\
\hline$<40 \mathrm{jam} /$ minggu & 33 & $3.036,36$ & & 603,023 & & $2822,54-3250,19$ \\
\hline \multicolumn{7}{|l|}{ Konsumsi Kafein } \\
\hline$<4$ gelas sehari & 31 & $2.670,97$ & 440,797 & 595,647 & 0,019 & $2452,48-2889,45$ \\
\hline Tidak mengkonsumsi kafein & 17 & $3.111,76$ & & 602,995 & & $2801,73-3421,80$ \\
\hline
\end{tabular}

Data primer

*) Uji T-Independent

Tabel 3 menunjukkan rata-rata berat badan lahir bayi dari ibu yang berusia $<20$ atau $>35$ tahun adalah $2.544,44$ gram, sedangkan rata-rata berat badan lahir bayi dari ibu yang berusia 20-35 tahun adalah 2.996,67 gram. Hasil uji statistik didapatkan $\mathrm{p}=0,014$ berarti pada alpha $5 \%$ terlihat ada perbedaan yang signifikan antara berat badan lahir bayi pada ibu yang berusia $<20$ tahun atau $>35$ tahun dan ibu yang berusia 20-35 tahun.

Tabel di atas juga menunjukkan ratarata berat badan lahir bayi dari ibu yang terpapar asap rokok selama hamil adalah 2.687,5 gram, sedangkan rata-rata berat badan lahir bayi dari ibu yang tidak terpapar asap rokok selama hamil adalah 3.106,25 gram. Hasil uji statistik didapatkan $\mathrm{p}=0,028$ berarti pada alpha $5 \%$ terlihat ada perbedaan yang signifikan antara berat badan lahir bayi pada ibu yang terpapar asap rokok selama hamil dan ibu yang tidak terpapar asap rokok selama hamil.

Rata-rata berat badan lahir bayi dari ibu terlalu lama berdiri selama melakukan aktivitas selama hamil dilihat dari tabel di atas adalah 2.366,67 gram, sedangkan rata-rata berat badan lahir bayi dari ibu yang tidak terlalu lama berdiri selama melakukan aktivitas selama hamil adalah 3.036,36 gram. Hasil uji statistik didapatkan $\mathrm{p}=0,000$ berarti pada alpha $5 \%$ terlihat ada perbedaan yang signifi- kan antara berat badan lahir bayi pada ibu yang terlalu lama berdiri selama hamil dan ibu yang tidak terlalul lama berdiri selama hamil.

Tabel 3 tersebut juga menunjukkan bahwa rata-rata berat badan lahir bayi dari ibu yang mengonsumsi kafein < 4 gelas sehari selama hamil adalah 2.670,97 gram, sedangkan rata-rata berat badan lahir bayi dari ibu yang tidak mengonsumsi kafein selama hamil adalah 3.111,76 gram. Hasil uji statistik didapatkan $\mathrm{p}=0,019$ berarti pada alpha 5\% terlihat ada perbedaan yang signifikan antara berat badan lahir bayi pada ibu yang mengkonsumsi kafein selama hamil dan ibu yang tidak mengonsumsi kafein selama hamil.

Berdasarkan beda mean yang diperoleh, maka disimpulkan bahwa faktor yang dominan berpengaruh terhadap perbedaan ratarata berat badan lahir bayi adalah lama berdiri dengan beda mean 669,697 gram $(p=0,000)$.

\section{PEMBAHASAN}

\section{Hubungan Usia ibu dengan Berat Badan Lahir Bayi}

Hasil penelitian ini menunjukkan bahwa hampir sebagian ibu bersalin berusia $<20$ tahun atau $>35$ tahun sehingga kelompok ini memiliki peluang untuk melahirkan bayi dengan berat badan lahir rendah. Hasil analisis bivariat membuktikan bahwa ibu yang berusia $<20$ tahun atau $>35$ tahun memiliki rata-rata 
berat badan lahir bayi berbeda bermakna dengan ibu yang berusia 20-35 tahun ( $p=$ 0,014 ) dengan beda rata-rata (mean) 452,222 gram.

Prognosa kehamilan sangat ditentukan oleh usia seseorang. Umur yang terlalu muda (kurang dari 20 tahun) dan umur yang terlalu tua (lebih dari 35 tahun) merupakan kehamilan resiko tinggi. Kehamilan pada usia muda merupakan faktor resiko hal ini disebabkan belum matangnya organ reproduksi untuk hamil (endometrium belum sempurna). Pada ibu remaja < 20 tahun peredaran darah menuju serviks dan juga menuju uterus masih belum sempurna sehingga hal ini dapat mengganggu proses penyaluran nutrisi dari ibu ke janin yang dikandungnya. Selain itu, ibu hamil $<20$ tahun perlu tambahan gizi yang banyak karena selain digunakan untuk pertumbuhan dan perkembangan dirinya sendiri juga harus berbagi dengan janin yang sedang dikandung guna mendukung kehamilan yang sedang berlangsung (Proverawati, 2010). Kondisi usia ibu yang masih muda sangat membutuhkan zat-zat gizi untuk pertumbuhan biologinya. Kebutuhan untuk pertumbuhan biologi ibu dan kebutuhan untuk janin dalam kandungannya merupakan dua hal yang pemenuhannya berlangsung melalui mekanisme yang kompetitif, di mana keadaan janin berada di pihak yang lemah sehingga dapat mengakibatkan terganggunya pertumbuhan janin dalam kandungan. Kehamilan pada usia $<20$ tahun secara biologis belum optimal sehingga emosinya cenderung labil, mentalnya belum matang sehingga mudah mengalami guncangan yang mengkibatkan kurangnya perhatian terhadap pemenuhan kebutuhan zat-zat gizi selama kehamilannya.

Kejadian bayi dengan berat badan lahir rendah (BBLR) juga meningkat seiring dengan pertambahan usia karena dengan meningkatnya usia akan terjadi perubahanperubahan pada pembuluh darah dan juga ikut menurunnya fungsi hormon yang mengatur siklus reproduksi. Di samping itu, semakin bertambahnya usia maka akan semakin meningkatkan pula risiko penyakit seperti hipertensi yang juga merupakan faktor predisposisi dari kelahiran bayi prematur dan BBLR
(Raymond, 2006). Semakin bertambahnya usia seorang wanita, maka hormon pengatur siklus reproduksi juga menurun. Salah satunya adalah hormon estrogen. Hormon estrogen merupakan hormon yang disekresikan oleh ovarium akibat respon dua hormon dari kelenjar hipofisis anterior. Hormon estrogen berfungsi meningkatkan aliran darah uterus dan perkembangan endometrium. Apabila kadar estrogen rendah dan perkembangan endometrium tidak sempurna, maka aliran darah ke uterus dapat menurun sehingga dapat mempengaruhi penyaluran nutrisi dari ibu ke janin. Selain menurunnya hormon esterogen akibat penambahan usia, hormon lain yang juga menurun adalah progesteron. Fungsi progesteron dalam masa kehamilan adalah mempertahankan agar kehamilan tetap berlanjut, progesteron ini mulai dihasilkan segera setelah plasenta terbentuk dan apabila kadar progesteron ini sedikit, maka persalinan akan bisa terjadi meski usia kehamilan masih belum cukup bulan (<37 minggu) sehingga menimbulkan persalinan prematur dan biasanya persalinan prematur ini diikuti dengan berat badan lahir rendah (Green, 2002). Kehamilan pada umur $<20$ tahun dan di atas 35 tahun juga dapat menyebabkan anemia, dimana anemia merupakan gangguan yang berisiko terhadap kejadian BBLR. Anemia dapat menyebabkan kurangnya suplai oksigen dan nutrisi pada plasenta yang akan berpengaruh pada fungsi plasenta terhadap pertumbuhan janin

Hasil penelitian ini sesuai dengan penelitian yang dilakukan oleh Suriani (2010) yang menunjukkan ada pengaruh yang signifikan antara usia ibu dengan kejadian BBLR. Hal ini juga sejalan dengan penelitian yang dilakukan oleh Colti Sistiarani (2008) yang menunjukkan hasil uji statistik didapatkan kesimpulan bahwa ada perbedaan yang signifikan persentase BBLR antara ibu yang termasuk kategori usia yang beresiko dengan ibu yang termasuk kategori usia yang tidak beresiko pada saat hamil dan melahirkan. Analisis faktor risiko usia didapatkan bahwa ibu yang termasuk kategori usia beresiko (usia kurang dari 20 tahun dan usia lebih dari 35 tahun) mempunyai peluang melahirkan BBLR 4,28 kali 
dibandingkan ibu yang tidak termasuk kategori usia yang beresiko (usia 20 tahun sampai dengan usia 35 tahun).

\section{Hubungan Paparan Asap Rokok dengan Berat Badan Lahir Bayi}

Hasil penelitian ini juga menunjukkan bahwa hampir sebagian ibu terpapar asap rokok selama hamil sehingga kelompok ini memiliki peluang untuk melahirkan bayi dengan berat badan lahir rendah. Hasil analisis bivariat membuktikan bahwa ibu yang terpapar asap rokok memiliki rata-rata berat badan lahir bayi berbeda bermakna dengan ibu tidak terpapar asap rokok $(p=0,028)$ dengan beda rata-rata (mean) 418,750.

Menurut Anwar (2008), ibu yang terpapar asap rokok yang mengandung nikotin bisa memacu gangguan kontraksi. Timbunan nikotin dalam darah bisa menghambat aliran darah dari ibu ke janin melalui tali pusat. Dengan begitu, kemampuan distribusi zat makanan yang diperlukan janin juga akan terganggu. Paparan asap yang terlalu sering seperti merokok dapat menyebabkan terjadinya plasenta abruption dan plasenta previa. Plasenta abruption dapat terjadi akibat pengurangan aliran darah ke plasenta yang akhirnya menyebabkan nekrosis pada periper dan plasenta. Sedangkan plasenta previa terjadi karena pembesaran plasenta sebagai akibat dari berkurangnya transport oksigen dari ibu ke fetus akibat paparan karbonmonoksida. Plasenta berubah secara tetap dengan kerusakan pada kemampuan plasenta untuk melakukan pertukaran gas karena terjadinya pengentalan dari trofoblastik basal lamina dan mengurangi ukuran pada kapiler dari fetus. Jika plasenta tersebut bermasalah, maka hal ini dapat mengganggu suplai makan ke janin. Karena lingkungan rahim tidak ideal maka janin tidak tumbuh dengan kecepatan yang semestinya. Maka tanpa adanya bantuan medis, bayi tersebut akan lahir kecil tidak sesuai usia kehamilan walaupun lahir tepat pada waktunya (Bobak \& Jensen, 2004).

Hal ini juga sesuai dengan penelitian yang dilakukan oleh Sirajuddin, dkk (2011) bahwa ada korelasi positif asap rokok terhadap berat badan bayi lahir, dengan $p=0,000$ $(p<0,05)$. Sedangkan penelitian oleh Harianti
Lestari (2007) menunjukan bahwa hubungan jumlah rokok yang diisap suami beresiko 9,322 (95 \% CI;3,692 -23,538) lebih besar bagi istrinya untuk melahirkan BBLR. Hasil penelitian Amiruddin (2007) juga menunjukkan hasil ibu-ibu yang terpapar rokok baik ibu sendiri yang merokok maupun terpapar oleh orang lain selama hamil memiliki kemungkinan 2,313 kali lebih besar mengalami BBLR dan prematur dibandingkan dengan ibu yang pada saat hamil tidak terpapar rokok.

Hasil penelitian ini juga sesuai dengan penelitian yang dilakukan oleh Sirajudin (2011) yang menunjukkan bahwa jika jumlah batang rokok yang diisap >25 batang/hari maka risiko kejadian BBLR $>1$. Artinya adalah jika seseorang merokok $>1$ bungkus sehari maka sudah dapat menyebabkan berat lahir bayi <2500 gram. Menurut Sirajuddin, merokok dapat memicu penebalan atau penyempitan pembuluh darah. Rokok dapat merangsang peningkatan denyut jantung dan tekanan darah dan juga mengandung karbon monoksida (CO) yang memiliki kemampuan jauh lebih kuat daripada sel darah merah (hemoglobin) untuk mengikat oksigen yang berakibat $\mathrm{CO}$ menurunkan kapasitas sel darah merah membawa oksigen ke jaringan-jaringan termasuk ke janin, sehingga dapat menganggu proses pertumbuhan janin dalam kandungan.

\section{Hubungan Lama Berdiri dengan Berat Badan Lahir Bayi}

Hasil penelitian ini menunjukkan bahwa hampir sebagian ibu dengan kegiatan lama berdiri lebih dari 40 jam seminggu sehingga kelompok ini memiliki peluang untuk melahirkan bayi dengan berat badan lahir rendah. Hasil analisis bivariat membuktikan bahwa ibu yang terlalu lama berdiri selama melakukan aktivitas selama hamil memiliki ratarata berat badan lahir bayi berbeda bermakna dengan ibu tidak terlalu lama berdiri selama melakukan aktivitas selama hamil $(p=0,000)$ dengan beda rata-rata (mean) 669,697 gram. Hal ini menunjukkan bahwa ada perbedaan yang bermakna ibu yang terlalu lama berdiri selama melakukan aktivitas selama hamil memiliki rata-rata berat badan lahir bayi berbeda bermakna dengan ibu tidak terlalu 
lama berdiri selama melakukan aktivitas selama hamil.

Terlalu lama berdiri membuat otot menjadi kaku sehingga secara efektif bisa mengurangi suplai darah ke otot-otot. Akibatnya aliran darah berkurang sehingga mempercepat timbulnya kelelahan dan menyebabkan nyeri pada otot-otot punggung, kaki dan leher (otot-otot ini digunakan untuk mempertahankan posisi tubuh). Ibu hamil yang bekerja kecenderungan memiliki waktu istirahat kurang yang akan mengakibatkan terjadinya komplikasi kehamilan, seperti terlepasnya plasenta yang secara langsung mempengaruhi BBLR. Hasil penelitian ini sesuai dengan penelitian yang dilakukan oleh Peoples Sheps dalam Nurhadi (2006), yang menunjukkan bahwa ibu hamil yang setiap harinya terlalu lama berdiri melahirkan bayi yang ukuran kepalanya satu sentimeter lebih kecil dibandingkan dengan ibu hamil yang tidak terlalu lama berdiri. Bekerja $\geq 40 \mathrm{jam} / \mathrm{mg}$ akan meningkatkan kejadian BBLR sebanyak 1,7 kali.

Dibandingkan dengan variabel lainnya, variabel ini memiliki $\mathrm{p}$ yang paling tinggi yaitu 0,000 dengan perbedaan mean paling besar yaitu 669,697 gram. Hal ini memberikan arti bahwa lama berdiri merupakan variabel yang memiliki pengaruh paling besar terhadap berat badan lahir bayi. Ibu yang terlalu lama melakukan aktivitas sambil berdiri dalam waktu yang lama dapat melakukan istirahat di sela-sela pekerjaannya untuk kembali meregangkan otot-otot yang tegang selama berdiri dalam keadaan statis.

\section{Hubungan Konsumsi Kafein dengan Berat Badan Lahir Bayi}

Hasil penelitian ini menunjukkan bahwa lebih dari sebagian ibu mengonsumsi kafein $<4$ gelas sehari selama hamil sehingga kelompok ini memiliki peluang untuk melahirkan bayi dengan berat badan lahir rendah. Hasil analisis bivariat membuktikan bahwa ibu yang mengonsumsi kafein memiliki rata-rata berat badan lahir bayi berbeda bermakna dengan ibu tidak mengonsumsi kafein $(\mathrm{p}=0,019)$ dengan beda rata-rata (mean) 440,797 gram. Hal ini menunjukkan bahwa ada perbedaan yang bermakna ibu yang mengonsumsi kafein dengan yang tidak mengonsumsi kafein terhadap berat badan lahir bayi, terlihat dari ratarata berat badan lahir bayi pada ibu yang mengkonsumsi kafein <4 gelas perhari lebih kecil dari pada rata-rata berat badan lahir bayi pada ibu yang tidak mengkonsumsi kafein.

Kafein dapat meningkatkan denyut jantung dan metabolisme, yang pada gilirannya mempengaruhi bayi yang sedang berkembang. Kafein juga merupakan zat diuretik, yang menyebabkan tubuh kehilangan air dan cairan lainnya yang semua itu dibutuhkan untuk mempertahankan kehamilan yang sehat serta dapat merusak kromosom yang meningkatkan kegiatan mutasi genetika. Kafein di dalam darah ibu masuk ke janin melalui plasenta. Hati janin belum memiliki enzim untuk memecah kafein karena enzim ini tidak akan terbentuk sebelum usia janin berusia matur. Oleh karena itu, wanita yang banyak minum kopi dan minuman ringan yang ditambah kafein, janin akan terus menerus terpapar kadar kafein yang tinggi sehingga berisiko BBLR (Hardinge, 2001).

Bech, et al (2007) juga mengatakan konsumsi kafein yang tinggi akan menyebabkan vasokonstriksi utero plasental, yang kemudian akan mengakibatkan malformasi fetus, infertilitas pada ibu, dan keadaan berat badan lahir rendah. Efek kafein terhadap ibu hamil akan terganggu dan menyebabkan resiko BBLR, bahkan sampai kepada malformasi fetus, kemungkinan hal ini diakibatkan oleh meningkatnya cycle adenosine monophospate (CAM) yang akan mengganggu perkembangan sel (Bech at al, 2007). Kafein juga dapat menyebabkan hipertensi, keadaan ini akan menimbulkan obstruksi lokal sirkulasi utero plasenta maternal yang mengakibatkan plasenta infark dan perubahan secara histologi plasenta dan kelangsungan hidup fetus. Apabila luas infark lebih dari 30\% dapat mengakibakan keadaan BBLR.

Hasil penelitian ini sesuai dengan penelitian yang dilakukan oleh Mardiawati, Dewi (2011) yang meneliti hubungan antara konsumsi kafein dengan berat badan lahir, menunjukkan bahwa ada hubungan yang rendah $(r=-0,493)$ dan berpola negatif, ini berarti semakin tinggi ibu hamil mengkonsumsi ka- 
fein maka semakin rendah berat badan lahir bayi. Secara statistik didapatkan hubungan yang bermakna antara konsumsi kafein dengan berat badan lahir dengan nilai $\mathrm{p}<0.05$ $(\mathrm{p}=0,001)$ dan persamaan garis regresi, berat badan lahir $=3577,425-3,093 \times$ Kafein. Hal ini menunjukkan adanya kecenderungan bahwa ibu hamil yang mengkonsumsi kafein pada masa kehamilan akan menurunkan berat badan bayi.

Michele (2011) dalam Mardiawati (2011) mengatakan bahwa kafein mengerutkan pembuluh darah ke rahim, sehingga aliran darah ke plasenta berkurang. Akibatnya, risiko melahirkan bayi berat lahir rendah menjadi lebih besar. Kafein juga dapat dengan mudah melewati pembuluh darah plasenta dan masuk ke dalam aliran darah janin dan meningkatkan denyut jantung janin. Kafein secara signifikan mengurangi aliran darah di vili plasenta (penyerapan zat gizi menjadi berkurang) dimana terjadinya penyempitan pembuluh darah. Janin mendapatkan segala yang dibutuhkan melalui aliran darah termasuk gizi, oksigenasi, jika terhambat janin akan kurang mendapatkan semua yang diperlukan untuk pertumbuhan dan perkembangan (Michele, 2011). Selain itu, menurut Suririnah (2008), kafein dapat meningkatkan hormon epineprin sehingga mengurangi aliran darah ke rahim sehingga penerimaan oksigen bayi maupun plasenta berkurang yang berarti berkurang juga penerimaan nutrisi untuk bayi. Akibatnya, dari penyempitan pembuluh darah ini mungkin dapat mengakibatkan gangguan perkembangan janin.

\section{KESIMPULAN}

Berdasarkan hasil penelitian disimpulkan yaitu hampir sebagian responden berusia $<20$ atau $>35$ tahun, sebagian besar responden terpapar asap rokok, hampir sebagian responden berdiri $\geq 40$ jam dalam seminggu selama

\section{DAFTAR RUJUKAN}

Anuranga, dkk. 2012. Trends, Inequalities And Determinants of Low Birth Weight in Sri Lanka. Jurnal Penelitian Ceylon Medical Vol. 57, No. 2, June 2012.61-69 melakukan aktivitas selama masa kehamilan, sebagian besar responden mengkonsumsi kafein <4 gelas sehari selama hamil, rata-rata berat badan lahir bayi di RSUD Dr. M. Yunus Kota Bengkulu adalah 2894 gram.

Hasil uji bivariat, penulis dapat menarik kesimpulan yaitu ada perbedaan rata-rata berat bayi lahir yang bermakna antara ibu yang berusia 20-35 tahun dengan ibu yang berusia $<20$ atau >35 tahun, ada perbedaan rata-rata berat bayi lahir yang bermakna antara ibu yang terpapar asap rokok dengan ibu yang tidak terpapar dengan asap rokok, ada perbedaan rata-rata berat bayi lahir yang bermakna antara ibu yang mengonsumsi kafein dengan ibu yang tidak mengonsumsi kafein, ada perbedaan rata-rata berat bayi lahir yang bermakna antara ibu yang terlalu lama berdiri selama melakukan kegiatan selama masa kehamilan dengan ibu yang tidak lama berdiri saat melakukan kegiatan selama hamil, serta faktor yang paling dominan dalam mempengaruhi berat badan lahir adalah lama berdiri selama hamil.

Hendaknya bidan di komunitas dapat melakukan suatu bentuk upaya promotifpreventif untuk mengurangi risiko terjadinya bayi lahir dengan berat badan rendah, seperti melakukan pengkajian terhadap ibu hamil pada K1 untuk mendeteksi secara dini faktorfaktor risiko yang terdapat pada ibu hamil tersebut yang dapat mengakibatkan masalah selama masa kehamilan, persalinan hingga nifas, serta mengambil tindakan segera yang dapat mengurangi terjadinya komplikasi pada ibu hamil tersebut sehingga dapat diambil tindakan konkrit yang tepat dalam mengatasi masalah pada ibu hamil. Selain itu, pendidikan kesehatan dan pemeliharaan kehamilan dan pemeriksaan secara berkala pada ibu hamil melalui posyandu, puskesmas, maupun kunjungan rumah.

Anwar dan Khomsan. 2008. Sehat Itu Mudah Wujudkan Hidup Sehat Dengan Makanan Tepat. Jakarta: Hikmah.

Bech, BH,Obel,C,Brink Hendersen,T dan Olsen,J. 2007. Effect of Reducing Caffeine Intake on Birth 
Weight and Length of Gestation. Jurnal British Medical, Vol.334, 409-412.

Bobak, Lowdermilk, Jensen. 2004. Buku Ajar Keperawatan Maternitas/Maternity Nursing. Alih Bahasa Maria A. Wijayanti. Peter I. Anugerah, edisi 4. Jakarta: EGC.

Budiman, Charles.2011. Korelasi antara Berat Badan Ibu Hamil dengan Berat Lahir Bayi di RSUP Dr.Kariadi pada Januari-Februari 2011. Yang terdapat dalam http://eprints.undip.ac.id diakses tanggal 1 Juli 2013.

Budiman, Charles.2011. Korelasi antara berat badan ibu hamil dengan berat lahir bayi di RSUP Dr.Kariadi pada Januari-Februari 2011. Yang terdapat dalam http://eprints.undip.ac.id diakses tanggal 1 Juli 2013.

Cuningham, F G, dkk.2006.Obstetri Williams I. Jakarta:EGC

Dinkes Provinsi Bengkulu, 2012. Profil Kesehatan Provinsi Bengkulu. Dinkes Provinsi Bengkulu

Glade B. Curtis, 2004, Kehamilan Di Atas Usia 30, Arcan Alih bahasa yasmin asih. Jakarta

Hasbullah, 2009. Dasar-Dasar Ilmu Pendidikan, Jakarta: Raja Grafindo Persada

Hidayat, Aziz Alimul. 2007.Metode Penelitian Kebidanan dan Teknik Analisis Data. Salemba Medika . Jakarta.

Hughes, Nancy dkk. 2011. Solutions for Prolonged Standing in Perioperative Settings. Jurnal Occupational and Environmental Medicine AORN J93 Vol. IV. June 2011. 767-774.

Mansjoer, Arif. 2004. Kapita Selekta Kedokteran Edisi Ketiga Jilid 2 cetakan ke 4. Media Aesculaprus FKUI. Jakarta.

Manuaba,I.B.G,2007. Ilmu Kebidanan, Penyakit Kandungan dan Kelurga Berencana. EGC.Jakarta.

Mardiawati, Dewi. Hubungan Konsumsi Kafein Pada Ibu Hamil Trimester III dengan Berat badan Lahir, Apgar Score, Plasenta di Kabupaten Padang Pariaman Tahun 2011. Program Pascasarjana Universitas Andalas. Sumatera Barat.

Mochtar.2007. Sinopsis Obstetri. Jakarta:EGC

Mubarak, W. I. 2007. Promosi Kesehatan Sebuah Pengantar Proses Belajar - Mengajar dalam Pendidikan. Yogyakarta: Graha Ilmu

Notoadmojo. 2010. Metode Penelitian Kesehatan. Jakarta : Rineka Cipta

Notoatmodjo. 2003. Pendidikan dan Perilaku Kesehatan. Jakarta : Rineka Cipta

Nurhadi. 2006. Faktor Risiko Ibu dan Layanan Antenatal terhadap Kejadian Bayi Berat Lahir Rendah( Studi kasus di BP RSUD Kraton Pekalongan). Program Pascasarjana Universitas Diponegoro. Semarang.

OECD. 2012. Health at A Glance Asia-Pacific. Yang terdapat pada www.oecd-ilibrary.org yang diakses tanggal 1 Juli 2013.
Proverawati, Atikah. 2010. Berat Badan Lahir Rendah. Yogyakarta: Nuha Medika.

Saifuddiun, 2002. Buku Acuan Nasional Pelayanan Kesehatan Maternal dan Neonatal . Yayasan Bina Pusaka. Sarwono Prawirohardjo. Jakarta.

Sastroasmoro. S.2002. Dasar-Dasar Metodologi Penelitian.Jakarta: Sagung Seto

SDKI. 2012. Angka Kematian Bayi. Diunduh dari www.bkkbn.go.id Diakses pada tanggal 1 Juli 2013.

Setianingrum, S.I.W. 2005. Hubungan Antara kenaikan Berat Badan, Lingkar Lengan Atas, dan Kadar Hemoglobin Ibu Hamil Trimester III dengan Berat Bayi Lahir di Puskesmas Ampel I Boyolali tahun 2005. Program Pascasarjana Universitas Negeri Semarang. Semarang.

Shelov. 2005. Panduan Lengkap Perawatan Untuk Bayi Dan Balita The American Academy Of Pediatrics. Jakarta : Penerbit Arcan.

Sidabutar, Romegawati. 2009. Hubungan Kebiasaan Merokok dengan Kejadian Partus Prematurus di Ruang Cl Kebidanan RSUD Dr. M. Yunus Bengkulu. Program D.III Kebidanan Poltekkes Kemenkes Bengkulu. Bengkulu.

Sirajuddin,dkk. 2011. Pengaruh Paparan Asap Rokok terhadap Kejadian Berat Badan lahir Bayi di Sulawesi Selatan tahun 2011. Jurnal Media Gizi Pangan Poltekkes Kemenkes Makassar, Vol. XI, Edisi 1, Januari - Juni 2011. 34-40.

Sistiarani, Colti. 2008. Faktor Maternal dan Kualitas Pelayanan Antenatal Care yang. Berisiko terhadap Kejadian Bayi Berat Lahir Rendah (BBLR) di RSUD Banyumas Tahun 2008. Program Pascasarjana Universitas Diponegoro. Semarang.

Siswono. 2008. Jaringan Informasi Pangan dan Gizi, volume XIV. Ditjen Bina Gizi Masyarakat. Jakarta.

Soetjiningsih. 2004. Tumbuh Kembang Anak. Jakarta: EGC.

Supariasa, I Dewa Nyoman, dkk. 2003. Penilaian Status Gizi. Jakarta: EGC

Suriani. 2010. Hubungan Kualitas Pelayanan Antenatal terhadap Kejadian Bayi Berat Lahir Rendah di Indonesia (Analisis Data Sekunder Survei Demografi dan Kesehatan Indonesia Tahun 2007). Program Pascasarjana Universitas Indonesia. Jakarta.

UU RI No 20. 2003. Sisdiknas. Jakarta: Wipress

WHO, 2007. Angka Kematian Bayi Di Indonesia Dengan Negara Lain. Yang terdapat dalam http://wwwE:Iprolangka kematian bayi di indonesia terhadap negara lainnya Kemenko Kesra.mht. yang diakses tanggal 1 Juli 2013.

Wiknjosastro.2007.Ilmu Kebidanan edisi III.Jakarta:Yayasan Bina Pustaka Sarwono Prawirohardjo. 